Energy Systems Environmental Restoration Program

ORNL Environmental Restoration Program

\title{
Toxicological Benchmarks for Screening Contaminants of Potential Concern for Effects on Sediment-Associated Biota: 1994 Revision
}

\author{
R. N. Hull ${ }^{1}$ \\ G. W. Suter II
}

Date Issued-June 1994

\author{
Prepared by \\ Environmental Sciences Division \\ Oak Ridge National Laboratory \\ and \\ Jaycor Environmental ${ }^{1}$ \\ Vienna, Virginia \\ Prepared for \\ U.S. Department of Energy
}

Office of Environmental Restoration and Waste Management

under budget and reporting code EW 20

OAK RIDGE NATIONAL LABORATORY

Oak Ridge, Tennessee 37831-6285

managed by

MARTIN MARIETTA ENERGY SYSTEMS, INC.

for the

U.S. DEPARTMENT OF ENERGY

under contract DE-AC05-84OR21400

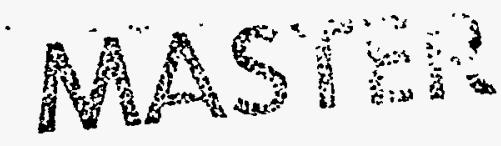


THIS PAGE INTENTIONALLY LEFT BLANK. 


\section{Author Affiliations}

R. N. Hull and G. W. Suter II are members of the Environmental Sciences Division of Oak Ridge National Laboratory, Martin Marietta Energy Systems, Inc.

\section{DISCLAIMER}

This report was prepared as an account of work sponsored by an agency of the United States Government. Neither the United States Government nor any agency thereof, nor any of their employees, makes any warranty, express or implied, or assumes any legal liability or responsibility for the accuracy, completeness, or usefulness of any information, apparatus, product, or process disclosed, or represents that its use would not infringe privately owned rights. Reference herein to any specific commercial product, process, or service by trade name, trademark, manufacturer, or otherwise does not necessarily constitute or imply its endorsement, recommendation, or favoring by the United States Government or any agency thereof. The views and opinions of authors expressed herein do not necessarily state or reflect those of the United States Government or any agency thereof. 
THIS PAGE INTENTIONALLY LEFT BLANK. 


\section{DISCLAIMER}

Portions of this document may be illegible in electronic image products. Images are produced from the best available original document. 


\section{CONTENTS}

TABLES $\ldots \ldots \ldots \ldots \ldots \ldots \ldots \ldots \ldots \ldots \ldots \ldots \ldots \ldots \ldots \ldots$ viii

ACRONYMS $\ldots \ldots \ldots \ldots \ldots \ldots \ldots \ldots \ldots \ldots \ldots \ldots \ldots \ldots \ldots \ldots \ldots \ldots$

ACKNOWLEDGMENTS $\ldots \ldots \ldots \ldots \ldots \ldots \ldots \ldots \ldots \ldots \ldots \ldots \ldots$

EXECUTIVE SUMMARY $\ldots \ldots \ldots \ldots \ldots \ldots \ldots \ldots \ldots \ldots \ldots \ldots \ldots$

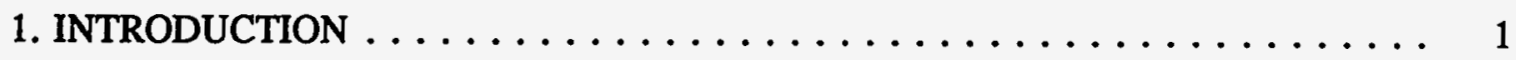

2. POSSIBLE APPROACHES TO SEDIMENT BENCHMARK DEVELOPMENT $\ldots \ldots 3$

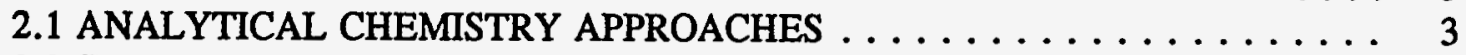

2.2 SEDIMENT TOXICITY TEST APPROACHES $\ldots \ldots \ldots \ldots \ldots \ldots$

2.3 FIELD SURVEY APPROACHES $\ldots \ldots \ldots \ldots \ldots \ldots \ldots \ldots$

2.4 INTEGRATIVE APPROACHES $\ldots \ldots \ldots \ldots \ldots \ldots \ldots \ldots \ldots \ldots \ldots$

2.5 BACKGROUND CONCENTRATIONS $\ldots \ldots \ldots \ldots \ldots \ldots \ldots \ldots \ldots$

3. APPROACHES USED TO DEVELOP SEDIMENT BENCHMARKS . . . . . . . 13

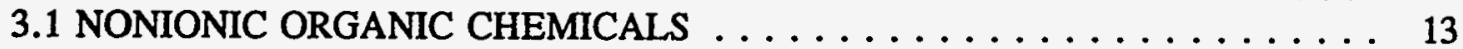

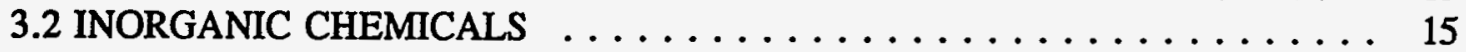

3.3 POLAR IONIC ORGANIC COMPOUNDS $\ldots \ldots \ldots \ldots \ldots \ldots \ldots$

4. BENCHMARK USE IN BASELINE ECOLOGICAL RISK ASSESSMENTS . . . . . 19

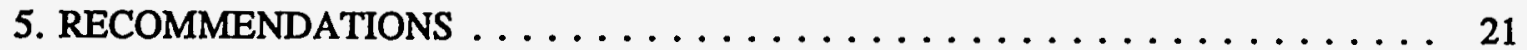

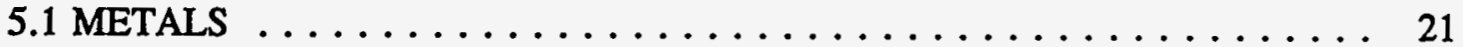

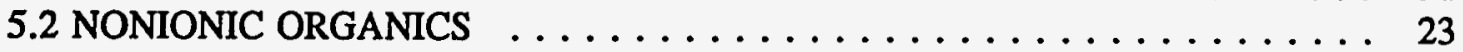

5.3 IONIC ORGANICS $\ldots \ldots \ldots \ldots \ldots \ldots \ldots \ldots \ldots \ldots \ldots \ldots \ldots$

6. UNCERTAINTIES/LIMITATIONS . . . . . . . . . . . . . . . 25

7. REFERENCES . . . . . . . . . . . . . . . . . . . 27 


\section{TABLES}

1. Summary of advantages of the various approaches to the development of SQBs . . . . 4

2. Summary of disadvantages of the various approaches to the development of $S Q B S \ldots . .5$

3. Information provided by differential sediment quality triad responses $\ldots \ldots \ldots \ldots 11$

4. Log octanol-water partition coefficient $\left(\log \mathrm{K}_{\mathrm{ow}}\right)$, $\log$ organic carbon-water partition coefficient ( $\log \mathrm{K}_{\mathrm{oc}}$ ), water quality benchmark (WQB), and sediment quality benchmark (SQB) for selected nonionic organic chemicals assuming $1 \%$ organic carbon $\ldots \ldots \ldots \ldots \ldots$

5. Summary of selected available sediment quality benchmarks for inorganic contaminants $(\mathrm{mg} / \mathrm{kg}$ dry weight $) \ldots \ldots \ldots \ldots \ldots \ldots \ldots \ldots \ldots \ldots$

6. Washington State sediment quality standards for ionizable organic compounds (micrograms

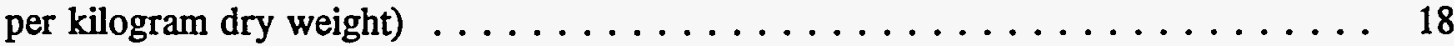




\section{ACRONYMS}

\begin{tabular}{ll} 
AET & apparent effects threshold \\
ARARs & applicable or relevant and appropriate requirements \\
ASTM & American Society for Testing and Materials \\
AVS & acid volatile sulfide \\
CERCLA & Comprehensive Environmental Response, Compensation, and Liability Act \\
DOC & dissolved organic carbon \\
EPA & U.S. Environmental Protection Agency \\
EqP & equilibrium partitioning \\
ERA & ecological risk assessment \\
ER-L & Effects Range-Low \\
ER-M & Effects Range-Median \\
f $_{\text {oc }}$ & fraction organic carbon \\
$\mathrm{K}_{\infty}$ & organic carbon/water partition coefficient \\
$\mathrm{K}_{\mathrm{ow}}$ & octanol/water partition coefficient \\
$\mathrm{K}_{\mathrm{p}}$ & sediment/water partition coefficient \\
MOE & Ministry of the Environment \\
NAWQC & National Ambient Water Quality Criteria \\
NOAA & National Oceanic and Atmospheric Administration \\
OC & organic carbon \\
ORNL & Oak Ridge National Laboratory \\
ORR & Oak Ridge Reservation \\
SEM & simultaneously extracted metal \\
SLC & screening level concentration \\
SQB & sediment quality benchmark \\
SQC & sediment quality criterion \\
SQG & sediment quality guideline \\
SSLC & species screening level concentration \\
TIE & toxicity identification evaluation \\
WI DNR & Wisconsin Department of Natural Resources \\
WQB & water quality benchmark \\
WQC & water quality criteria \\
& \\
\hline
\end{tabular} 
THIS PAGE INTENTIONALLY LEFT BLANK. 


\section{ACKNOWLEDGMENTS}

The manuscript benefitted from the review comments of Lynn Kszos and Adrian Gonzales. 
THIS PAGE INTENTIONALLY LEFT BLANK. 


\section{EXECUTIVE SUMMARY}

Because a hazardous waste site may contain hundreds of chemicals, it is important to screen contaminants of potential concern for the ecological risk assessment. Often this screening is done as part of a Screening Assessment, the purpose of which is to evaluate the available data, identify data gaps, and screen contaminants of potential concern. Screening may be accomplished by using a set of toxicological benchmarks. These benchmarks are helpful in determining whether contaminants warrant further assessment or are at a level that requires no further attention. If a chemical concentration or the reported detection limit exceeds a proposed lower benchmark, more analysis is needed to determine the hazards posed by that chemical. If, however, the chemical concentration falls below the lower benchmark value, the chemical may be eliminated from further study.

This report briefly describes three categories of approaches to the development of sediment quality benchmarks. These approaches are based on analytical chemistry, toxicity test results, and field survey data. A fourth integrative approach incorporates all three types of data.

The equilibrium partitioning approach is recommended for screening nonpolar organic contaminants of concern in sediments. For inorganics, the National Oceanic and Atmospheric Administration has developed benchmarks that may be used for screening. There are supplemental benchmarks from the province of Ontario, the state of Wisconsin, and U.S. Environmental Protection Agency Region V. Pore water analysis is recommended for polar organic compounds; comparisons are then made against water quality benchmarks.

This report is an update of a prior report (Hull and Suter, 1993). It contains revised ER-L and ER-M values, the five EPA proposed sediment quality criteria, and benchmarks calculated for several nonionic organic chemicals using equilibrium partitioning. 
THIS PAGE INTENTIONALLY LEFT BLANK.

xiv 


\section{INTRODUCTION}

Because a hazardous waste site may contain hundreds of chemicals, it is important to screen contaminants of potential concern for the ecological risk assessment (ERA). Often this screening is done as part of a Screening Assessment, the purpose of which is to evaluate the available data, identify data gaps, and screen contaminants of potential concern. Screening may be accomplished by using a set of toxicological benchmarks. These benchmarks are helpful in determining whether contaminants warrant further assessment or are at a level that requires no further attention. If a chemical concentration or the reported detection limit exceeds a lower benchmark, more analysis is needed to determine the hazards posed by that chemical. If, however, the chemical concentration falls below the lower benchmark value, the chemical may be eliminated from further study. Concentrations exceeding an upper screening benchmark indicate that the chemical in question is clearly of concern and that remedial actions are likely to be needed.

In recent years, protecting sediment quality has been viewed as a logical and needed extension of water quality protection (Adams, Kimerle, and Barnett, Jr. 1992). The U.S. Environmental Protection Agency (EPA) is authorized to develop and implement sediment quality criteria (SQC) under Section 304(a) of the Clean Water Act (EPA 1989a). EPA released five SQC documents in 1993 (EPA 1993a-e). Until EPA's task is complete, efforts will continue around the United States and abroad (MacDonald 1993; Persaud, Jaagumagi, and Hayton 1990) to develop SQC and benchmark values for the assessment of sediment quality at hazardous waste sites.

Sediment quality benchmarks (SQBs) are necessary, in addition to water quality benchmarks (WQBs), because

- various toxic contaminants found in only trace amounts in the water column accumulate in sediments to elevated levels;

- sediments serve as both a reservoir and a source of contaminants to the water column;

- sediments integrate contaminant concentrations over time, whereas water column contaminant concentrations are much more variable and dynamic;

- sediment contaminants in addition to water column contaminants affect benthic and other sediment-associated organisms; and

- sediments are an integral part of the aquatic environment, providing habitat, feeding, and rearing areas for many aquatic organisms (Chapman 1989).

To make decisions as to whether a chemical or biological measurement of sediment quality indicates impairment, site-specific data may be compared with benchmarks that indicate whether sediment quality is acceptable. Existing criteria and standards are considered a type of benchmark. The purpose of this report is to present sediment benchmark data and discuss their use as benchmarks for determining the level of toxicological effects on sediment-associated biota. 
Note, however, that these benchmarks do not represent remediation goals. Remediation goals must consider adverse effects on habitat and remobilization of contaminants caused by removal or remediation of sediments.

The benchmarks in this report are to be used at the U.S. Department of Energy's (DOE's) Oak Ridge Reservation (ORR) and at the Portsmouth and Paducah Gaseous Diffusion plants as screening values only to show the nature and extent of contamination and identify the need for additional site-specific investigation (e.g., biological and chemical testing).

Sediment benchmarks also can be used for baseline ERAs, which are required under the Comprehensive Environmental Response, Compensation, and Liability Act (CERCLA) at Superfund sites. These assessments evaluate the risks to the environment posed by the hazardous waste site. Sediment benchmarks must not be used as the sole measure of sediment toxicity. Field studies and toxicity tests shall be the primary indicators of toxicity of sediments; benchmarks may be used to determine which chemicals present in the sediment are most likely causing the toxicity. This integrative approach allows a more accurate evaluation of adverse ecological impact, which is necessary in a baseline risk assessment.

This report is an update of a prior report (Hull and Suter, 1993). It contains revised ER-L and ER-M values, the five EPA proposed sediment quality criteria, and benchmarks calculated for several nonionic organic chemicals using equilibrium partitioning. 


\section{POSSIBLE APPROACHES TO SEDIMENT BENCHMARK DEVELOPMENT}

There are three distinct categories of approaches to the development of SQBs. These approaches are based on analytical chemistry, toxicity test results, and field survey data. A fourth integrative approach incorporates all three types of data. Regardless of the method, a numeric benchmark results.

The scientific and regulatory communities are still debating the best methods to be used to develop sediment quality guidelines. This diversity of opinion is demonstrated by the wide variety of methods being studied and by the fact that the state of Washington has implemented sediment quality standards based on the apparent effects threshold (AET) approach, whereas the equilibrium partitioning (EqP) approach is favored by the EPA Office of Water and Regulations (Adams, Kimerle, and Barnett, Jr. 1992). The Organization for Economic Cooperation and Development (OECD 1992) released a report on effects assessment of chemicals in sediment. This report evaluates eight methods for developing sediment quality objectives. Based on the evaluation criteria outlined in the report, three methods were recommended for deriving sediment quality objectives: the EqP approach, the measurement of interstitial water, and spiked sediment toxicity tests.

Several of the possible approaches to developing SQBs are described in the following sections. The various methods have been reviewed recently (Adams, Kimerle, and Barnett, Jr. 1992; MacDonald et al. 1992; Chapman 1989). A summary of some of the advantages and disadvantages of each of these approaches is given in Tables 1 and 2.

\subsection{ANALYTICAL CHEMISTRY APPROACHES}

\subsubsection{Water Quality Benchmark Approaches}

\subsubsection{Direct measurement of interstitial water}

The direct measurement of interstitial water approach compares the concentrations of contaminants in sediment interstitial (pore) waters with the EPA water quality criteria (WQC) (EPA 1986) and other WQBs. WQBs of varying conservatism have been developed at Oak Ridge National Laboratory (ORNL) (Suter and Mabrey 1994) because many chemicals do not have national ambient WQC. Maughan (1993) suggests that the analysis of sediment pore water is a more appropriate method for screening than using bulk sediment chemistry. He cites the advantages of the flexibility and acceptance of pore water testing.

It can be argued that benthic organisms are exposed to contaminants via other exposure routes, such as dermal absorption and ingestion of sediment particles. An analysis of freshwater benthic species' feeding habits concluded that these species were not sediment ingesters, with the exception of the oligochaetes (aquatic earthworms) and some chironomids that are both filter feeders and occasionally sediment ingesters (Adams 1987). In contrast to this, marine burrowing species frequently ingest sediment (Adams 1987). For the clam Macoma nasuta, uptake of highly lipophilic pollutants occurred primarily by ingestion of solids (63 to $84 \%$ ), followed by ventilation of interstitial water across the gills (11 to 12\%) (Boese et al. 1990). This may be 
Table 1. Summary of advantages of the various approaches to the development of SQBs ${ }^{a}$

\begin{tabular}{|c|c|c|c|c|c|c|c|}
\hline Approach & Simple & $\begin{array}{l}\text { Useful for } \\
\text { metal } \\
\text { toxicity }\end{array}$ & $\begin{array}{c}\text { Uses } \\
\text { existing } \\
\text { WQC }\end{array}$ & $\begin{array}{l}\text { Accepted } \\
\text { methods }\end{array}$ & $\begin{array}{c}\text { Used with } \\
\text { any } \\
\text { chemical }\end{array}$ & $\begin{array}{l}\text { Combined } \\
\text { chemical } \\
\text { effects } \\
\text { determined }\end{array}$ & $\begin{array}{c}\text { Effects } \\
\text { based }\end{array}$ \\
\hline Background & $\mathrm{X}$ & & & $\mathrm{X}$ & & & \\
\hline Pore water & & $\mathrm{X}$ & $\mathrm{x}$ & & & & $\mathrm{X}$ \\
\hline $\mathrm{Eq}^{a}$ & & & $\mathrm{x}$ & $\mathrm{x}$ & & & $\mathrm{x}$ \\
\hline $\mathrm{AVS}^{a}$ & & $\mathrm{X}$ & & $\mathrm{x}$ & & & $\mathrm{x}$ \\
\hline $\begin{array}{l}\text { Toxicity } \\
\text { tests }\end{array}$ & & & & & $\mathrm{X}$ & $\mathrm{X}$ & $\mathrm{X}$ \\
\hline $\operatorname{SLC}^{a}$ & & & & $\mathrm{X}$ & $\mathrm{X}$ & & $\mathrm{x}$ \\
\hline $\mathrm{AET}^{a}$ & & & & $\mathrm{x}$ & $\mathrm{X}$ & $\mathbf{X}$ & $\mathbf{x}$ \\
\hline Triad & & & & & $\mathrm{X}$ & $\mathrm{X}$ & $\mathrm{x}$ \\
\hline $\mathrm{NOAA}^{a}$ & $\mathrm{x}$ & $\mathrm{X}$ & & & & & $\mathrm{X}$ \\
\hline
\end{tabular}

aSQBs = sediment quality benchmarks; WQC = water quality criterion; $\mathrm{EqP}=$ equilibrium partitioning; $\mathrm{AVS}=$ acid volatile sulfide; SLC $=$ screening level concentration; $\mathrm{AET}=$ apparent effects threshold; NOAA $=$ National Oceanic and Atmospheric Administration. 
Table 2. Summary of disadvantages of the various approaches to the development of SQBS

\begin{tabular}{|c|c|c|c|c|c|c|c|c|c|}
\hline Approach & $\begin{array}{l}\text { Site- } \\
\text { specific }\end{array}$ & $\begin{array}{c}\text { No } \\
\text { biological } \\
\text { basis }\end{array}$ & $\begin{array}{l}\text { Inorganics } \\
\text { only }\end{array}$ & $\begin{array}{c}\text { Nonpolar } \\
\text { organics } \\
\text { only }\end{array}$ & $\begin{array}{l}\text { Large field } \\
\text { effort } \\
\text { required }\end{array}$ & $\begin{array}{c}\text { Cannot } \\
\text { distinguish } \\
\text { between } \\
\text { one and } \\
\text { several } \\
\text { chemicals }\end{array}$ & $\begin{array}{l}\text { Cannot be } \\
\text { used for } \\
\text { synthetic } \\
\text { organics }\end{array}$ & $\begin{array}{l}\text { Missing } \\
\text { standard } \\
\text { methods }\end{array}$ & $\begin{array}{c}\text { Sampling } \\
\text { may alter } \\
\text { toxicity }\end{array}$ \\
\hline Background & & $\mathrm{X}$ & & & & & $\mathrm{x}$ & & \\
\hline Pore water & & & & & & & & $\mathrm{X}$ & $\mathrm{x}$ \\
\hline $\mathrm{Eq}^{a}$ & & & & $\mathrm{X}$ & & & & & \\
\hline $\mathrm{AVS}^{a}$ & & & $\mathrm{x}$ & & & & $\mathrm{X}$ & & \\
\hline $\begin{array}{l}\text { Toxicity } \\
\text { tests }\end{array}$ & & & & & $\mathrm{X}$ & $\mathrm{X}$ & & $\mathrm{X}$ & $\mathrm{x}$ \\
\hline $\mathrm{SLC}^{a}$ & & & & & $\mathrm{x}$ & $\mathrm{x}$ & & & \\
\hline $\mathrm{AET}^{a}$ & $\mathrm{x}$ & & & & $\mathrm{x}$ & $\mathrm{x}$ & & . & \\
\hline Triad & & & & & $\mathrm{x}$ & & & $\mathrm{x}$ & \\
\hline $\mathrm{NOAA}^{a}$ & & & & & & & & $X$ & \\
\hline
\end{tabular}

${ }^{a} \mathrm{SQBs}=$ sediment quality benchmarks; EqP = equilibrium partitioning; AVS = acid volatile sulfide; SLC = screening level concentration; AET = apparent effects threshold; NOAA = National Oceanic and Atmospheric Administration. 
because Macoma nasuta predominantly ventilates overlying water, not interstitial water. Such discrimination between overlying and interstitial water also may be important for tube dwellers (e.g., chironomids and hexagenia) that pump overlying water through their burrows (Landrum and Robbins 1990). Maughan (1993) argues that if the organism is in equilibrium with the pore water, then the concentration in the pore water would reflect the sum of all exposure routes. Therefore, an organism that has accumulated contaminants, through feeding, at a higher concentration than the equilibrium with pore water would re-establish the equilibrium by losing contaminants to the pore water (Maughan 1993). However, factors may influence whether the organism can establish an equilibrium with the pore water. For example, diffusion within the interstitial water may limit transfer of desorbed compounds to the organism (Landrum and Robbins 1990).

Direct measurement of pore water would yield useful information for contaminants lacking bulk sediment contaminant benchmarks (e.g., polar organics). However, this is not recommended if estimation of the pore water concentration can be done using the EqP approach for reasons explained in the following text.

\subsubsection{Estimation of interstitial water concentrations: sediment/water equilibrium partitioning approach}

Nonionic organics. This approach calculates a bulk sediment chemical concentration benchmark. The calculation uses the WQBs together with correction factors for the effects of organic carbon (OC) (EPA 1989a).

An SQB using this method is calculated as follows (EPA 1989a): If WQB (micrograms per liter) is a water quality benchmark for the chemical of interest (see Suter and Mabrey 1994), then the sediment quality benchmark, SQB (micrograms per kilogram sediment), is computed using the partition coefficient $K_{p}$ (liters per kilogram sediment) between sediment and water:

$$
\mathrm{SQB}=\mathrm{K}_{\mathrm{p}} \times \mathrm{WQB}
$$

The partitioning of nonionic chemicals between particles and water depends on the partition coefficient $K_{o c}$ for the particles' OC and the mass fraction of $O C f_{o c}$ (kilograms OC per kilogram sediment) of the particles:

$$
K_{p}=f_{\alpha} \times K_{\alpha} \text {. }
$$

Where the $K_{o c}$ is unavailable, it is estimated by the octanol-water partition coefficient $K_{o w}$ of the chemical for sediments using the following equation (Di Toro 1985):

$$
\log _{10}\left(K_{\propto}\right)=0.00028+0.983 \log _{10}\left(K_{\alpha w}\right) \text {. }
$$

Therefore,

$$
\mathrm{SQB}=\mathrm{f}_{\mathrm{oc}} \times \mathrm{K}_{\text {ow }} \times \mathrm{WQB} .
$$

The EqP approach makes three assumptions: 1) the sensitivities of benthic species and species tested to derive WQC, predominantly water column species, are similar; 2) the levels of protection afforded by WQC are appropriate for benthic organisms; and 3) exposures are similar regardless of feeding type or habitat (EPA 1993a). 
EqP can be used only if $f_{o c}>0.5 \%$. At $f_{o c}<0.5 \%$, the factors controlling second-order effects on partitioning (e.g., particle size, sorption to nonorganic mineral fractions) become relatively more important (EPA 1989a).

For both the direct and indirect approaches for estimating pore water concentrations, it is assumed that the WQBs, when applied to the interstitial water of sediments, would protect infaunal organisms. EPA (1989a) has concluded that the sensitivities of benthic species are sufficiently similar to those of water column species to tentatively permit the use of WQBs for the derivation of SQBs.

The EqP approach is favored by the EPA over the direct measuring of pore water approach (EPA 1989a). The free chemical concentration in pore water can be estimated directly from the OC normalized sediment concentration, and the estimate is independent of the dissolved organic carbon (DOC) concentration. Using the pore water chemical concentration to estimate the free pore water chemical concentration requires that the DOC concentration and the DOC partition coefficient be known. This is because the proportion of a chemical in pore water that is complexed to DOC can be substantial. However, it is the free, uncomplexed component that is bioavailable and that is in equilibrium with the $\mathrm{OC}$ normalized sediment concentration. Therefore, for highly hydrophobic chemicals and where there is significant DOC complexing, the solid-phase chemical concentration gives a more direct estimate of the bioavailable pore water contaminant concentration than do the pore water concentrations (EPA 1989a).

Metals: acid volatile sulfide method. Acid volatile sulfide (AVS) is a reactive pool of solidphase sulfide that is available to bind metals and render that portion unavailable and nontoxic to biota (Di Toro et al. 1992). The AVS is extracted from sediment using hydrochloric acid. The metal concentration that is simultaneously extracted is termed the simultaneously extracted metal (SEM). For [SEM]/[AVS] $<1$, no acute toxicity (mortality $>50 \%$ ) has been observed in any sediment for any benthic test organism. For [SEM]/[AVS] $>1$, less sensitive organisms can tolerate increased metal activity. However, the mortality of sensitive species (e.g., amphipods) increases in the range of 1.5 to $2.5 \mu \mathrm{mol}$ of SEM/ $\mu \mathrm{mol}$ of AVS (Di Toro et al. 1992). For this reason, the AVS method is used only to predict when a sediment in not acutely toxic.

The AVS approach requires the measurement of all toxic SEMs that are present in amounts that would contribute significantly to the SEM sum. Failure to do so could lead to an incorrect conclusion of lack of acute toxicity (Di Toro et al. 1992). Use of the AVS method would be invalid if the sediment AVS content is very low. This would occur in fully oxidized sediments (Adams, Kimerle, and Barnett, Jr. 1992). In addition, the AVS method has not been adapted for chronic toxicity.

The AVS method is seldom applicable to screening risk assessments because the needed data are not available. It is not recommended for baseline risk assessments because its validity is not generally accepted. 


\subsection{SEDIMENT TOXICITY TEST APPROACHES}

\subsubsection{Bulk Sediment Toxicity Tests}

Organisms are exposed to either contaminated field-collected sediments or background sediments spiked in the laboratory with known amounts of single chemicals or mixtures. Mortality or sublethal effects are observed, and dose-response relationships are determined (Chapman 1989; Long and Morgan 1991). A major advantage to this approach is that it follows the methods used to develop WQC; therefore, the procedure and rationale are technically acceptable and legally defensible (Chapman 1989). The use of sediment toxicity tests has become firmly entrenched in many dredged material permitting and benthic survey programs (Burton and Scott 1992). Several disadvantages include the following: toxicity tests do not provide chemicalspecific benchmarks; toxicity test methods have yet to be standardized; and toxicity tests may not reflect chronic effects (Chapman 1989).

This approach is too costly and labor intensive for screening purposes, and frequently the data are not available. It is recommended that bulk sediment toxicity tests be incorporated into a baseline ERA sampling and analysis plan.

\subsubsection{Pore Water Toxicity Tests}

Sediment pore water can be used in standardized toxicity tests, and toxicity identification evaluation (TIE) procedures can be used to characterize, identify, and then confirm the toxic components of a complex aqueous solution. However, TIE procedures may be difficult and costly (Maughan 1993). Currently, no universally accepted method for extracting pore water from sediment exists. In addition, pore water is difficult to extract from sediment without potentially altering the toxicity of the pore water (Maughan 1993).

Pore water toxicity tests could be incorporated into screening and baseline ERAs if bulk sediment toxicity tests cannot be used.

\subsection{FIELD SURVEY APPROACHES}

\subsubsection{Screening Level Concentration Approach}

The screening level concentration (SLC) approach estimates the highest concentration of a particular contaminant in sediment that can be tolerated by $\sim 95 \%$ of benthic infauna (Neff et al. 1988). The SLC is derived from synoptic data on sediment chemical concentrations and benthic invertebrate distributions. First, the species screening level concentration (SSLC) is calculated by plotting the frequency distribution of the contaminant concentrations over all sites (at least 10) where the species is present. The 90th percentile of this distribution is taken as the SSLC for that species. Next, a large number of SSLCs are plotted as a frequency distribution to determine the contaminant concentration above which $95 \%$ of the SSLCs occur. This final concentration is the SLC (Neff et al. 1988).

The SLC approach has several advantages: it can be used with any chemical contaminant; it can be developed using existing data bases and methodologies; and it does not require a priori 
assumptions concerning mechanisms of interaction between organisms and toxic contaminants (Chapman 1989). Disadvantages include the following:

- A large amount of field data is required.

- A precise level of infaunal taxonomic identification is required.

- Calculation of SLCs is affected by the range and distribution of contaminant concentrations and species.

- Selection criteria for species have not been established.

- No mechanism has been established to separate single contaminant effects from the effects of all contaminants combined (Chapman 1989).

The SLC method is not recommended for benchmark development because of the numerous disadvantages. However, it could be appropriate for development of remedial action goals for a site.

\subsubsection{Apparent Effects Threshold Approach}

The AET approach uses data from matched sediment chemistry and biological effects measures. Biological effects could be assessed by either benthic community survey or sediment toxicity tests. An AET concentration is the sediment concentration of a selected chemical above which statistically significant biological effects always occur (EPA 1989b).

The major strengths of the approach are:

- combined chemical effects can be considered (EPA 1989b);

- there are no constraints on the type of contaminant or biological effects that can be used;

- contaminants that are most likely associated with observed biological effects are identified on a site-specific basis; and

- because observed biological effects always occur above the AET, the approach provides values based on noncontradictory evidence of biological impacts (Chapman 1989).

Disadvantages to this approach include the following:

- It is site specific (EPA 1989b).

- It may be underprotective because biological effects are observed at chemical concentrations well below AET values.

- This method requires a large data base for chemical variables and at least one biological indicator.

- Combined contaminant effects cannot be separated from single contaminant effects (Chapman 1989). 
The AET approach is not recommended for benchmark development. However, existing AET values can be used in the screening of potential contaminants of concern (see Subsect. 3.2).

\subsection{INTEGRATTVE APPROACHES}

\subsubsection{Sediment Quality Triad}

The sediment quality triad approach is based on correspondences between three measures: sediment chemistry to determine contamination, sediment toxicity tests to determine toxicity, and in situ bioeffects (e.g., benthic infaunal community structure) to determine alteration of resident communities (Chapman 1989). Table 3 describes the information provided by various responses to these three measures.

The major advantage of the triad approach is that the combination of the three separate measures in a weight-of-evidence approach allows for differentiation of toxicity related to contamination from natural variability and/or laboratory artifacts (Chapman 1989). The approach incorporates interactions between contaminants in complex sediment mixtures, including additivity, antagonism, and synergism; actions of unidentified toxic chemicals; and effects of environmental factors that influence biological responses. A major disadvantage is that this method is both labor intensive and expensive (Chapman, Power, and Burton, Jr. 1992).

An integrative approach is required for a technically complete baseline ERA, especially at a large waste site with numerous contaminants in several media and where there are potentially several exposure pathways. This approach is pursued for baseline ERAs at DOE sites, such as the ORR (Suter et al. 1992). Although the full triad of sediment data is not available for screening assessments, the weight of evidence should be considered whenever multiple measures are available.

\subsubsection{National Oceanic and Atmospheric Administration Approach}

Complexities are associated with inorganic chemicals when using the EqP approach. Uptake (and therefore effects) of sediment-associated contaminants is largely a function of bioavailability. Bioavailability is strongly influenced by a complex suite of physical, chemical, and biological factors in the sediments. Trace metals can be adsorbed at particle surfaces, bound to carbonates, occluded in iron and/or manganese oxyhydroxides, bound to organic matter, bound to sulphide, bound to a matrix, or dissolved in the interstitial water. The complexity of trace metal bioavailability associated with these phases hinders the prediction of effects (Campbell and Tessier 1991).

Because the EqP approach is impractical for inorganics, other benchmark values were needed. The National Oceanic and Atmospheric Administration (NOAA) Long and Morgan (1991) report methodology is under consideration for development of SQC and screening values by state agencies and the government of Canada (Fox 1991; MacDonald et al. 1992). NOAA annually collects and chemically analyzes sediment samples from sites located in coastal marine and estuarine environments throughout the United States. The data were used to evaluate three basic approaches to the establishment of effects-based criteria: the EqP approach, the spiked-sediment toxicity test approach, and various methods of evaluating synoptically collected biological and chemical data in field surveys. Chemical concentrations observed or predicted by these methods to be associated with biological effects were ranked, and the lower 10th percentile [Effects 
Table 3. Information provided by differential sediment quality triad responses

\begin{tabular}{|c|c|c|c|c|}
\hline Situation & $\begin{array}{l}\text { Chemicals } \\
\text { present }\end{array}$ & Toxicity & Alteration & Possible conclusions \\
\hline 1 & + & + & + & $\begin{array}{l}\text { Strong evidence for pollution-induced } \\
\text { degradation }\end{array}$ \\
\hline 2 & - & - & - & $\begin{array}{l}\text { Strong evidence that there is no pollution- } \\
\text { induced degradation }\end{array}$ \\
\hline 3 & + & - & - & $\begin{array}{l}\text { Contaminants are not bioavailable or are } \\
\text { present at nontoxic levels }\end{array}$ \\
\hline 4 & - & + & - & $\begin{array}{l}\text { Unmeasured chemicals or conditions exist } \\
\text { with the potential to cause degradation }\end{array}$ \\
\hline 5 & - & - & + & Alteration is not due to toxic chemicals \\
\hline 6 & + & + & - & Toxic chemicals are stressing the system \\
\hline 7 & - & + & + & $\begin{array}{l}\text { Unmeasured toxic chemicals are causing } \\
\text { degradation }\end{array}$ \\
\hline 8 & + & - & + & $\begin{array}{l}\text { Toxicity tests are insufficiently sensitive } \\
\text { or alteration is not due to toxic chemicals }\end{array}$ \\
\hline
\end{tabular}

Tesponses are shown as either positive $(+)$ or negative $(-)$, indicating whether or not measurable (e.g., statistically significant) differences from control/reference conditions/measures are determined.

Source: Chapman, P. M. 1990. "The Sediment Quality Triad Approach to Determining Pollution-Induced Degradation." Sci.

Total Environ. 97/98, 815-825.

Range-Low (ER-L)] and median [Effects Range-Median (ER-M)] concentrations were identified.

The ER-L and ER-M values were recalculated by Long et al. (1993) after omitting the few freshwater data included in the Long and Morgan (1991) calculations and after adding additional, more recent data. These revised ER-L and ER-M values are recommended for screening contaminants of potential concern.

\subsection{BACKGROUND CONCENTRATIONS}

Comparison of site contaminant levels with background levels is a simple screening method. The assumption is that concentrations that are not higher than background are not hazardous. Appropriate background samples must be obtained for waste site samples. The American Society for Testing and Materials (ASTM) is currently developing guidelines for selection of sediment and soil background sampling locations (ASTM Section E47.13.01, Task E).

This approach has two major disadvantages: it has no biological effects basis, and it cannot be used for synthetic organic compounds, which should not be present in background sediments. Therefore, this approach should not be used as the only screening method. It is appropriate to use the background concentrations to screen the other sediment benchmarks. Sediment benchmarks that are below background contaminant concentrations are not retained as benchmarks when screening site sediments. 


\section{APPROACHES USED TO DEVELOP SEDIMENT BENCHMARKS}

\subsection{NONIONIC ORGANIC CHEMICALS}

The EPA has chosen the EqP approach for developing SQC for nonionic organics (EPA 1989a). This is also a methodology that ORNL supports for developing SQBs when bulk sediment concentrations and WQBs are available.

The EqP approach requires certain information for the development of the benchmark. The WQB is paramount to the calculation. Because many chemicals do not have National Ambient Water Quality Criteria (NAWQC), sets of WQBs of varying conservatism have been developed at ORNL (Suter and Mabrey 1994). Table 4 lists the available $\log \mathrm{K}_{\text {ow }}$ values for selected organic contaminants, along with the calculated $\log \mathrm{K}_{\mathrm{cc}}$, the WQB required for the calculation of the SQB, and the final SQB. The primary source of the $K_{\text {ow }}$ values was EPA $(1992 ; 1994)$. The EPA (1994) values take precedence. EPA SQC exist for five contaminants (EPA 1993a-e). These criteria values are listed also in Table 4.

After the sediment benchmarks have been calculated, comparisons can be made to site sediment contaminant concentrations. The data required for this comparison include the bulk sediment contaminant concentration and the fraction $O C\left(f_{\infty}\right)$ of the sediment. No other measurements are required.

Table 4. Log octanol-water partition coefficient $\left(\log \mathrm{K}_{\mathrm{ow}}\right)$, $\log$ organic carbon-water partition coefficient $\left(\log K_{o c}\right)$, water quality benchmark (WQB), and sediment quality benchmark (SQB) for selected nonionic organic chemicals assuming $1 \%$ organic carbon

\begin{tabular}{lcccc}
\hline \multicolumn{1}{c}{ Contaminant } & $\log \mathrm{K}_{\mathrm{ow}}$ & $\log \mathrm{K}_{\mathrm{cc}}$ & $\begin{array}{c}\text { WQB } \\
(\mathrm{mg} / \mathrm{L})\end{array}$ & $\begin{array}{c}\mathrm{SQB} \\
(\mathrm{mg} / \mathrm{kg})\end{array}$ \\
\hline Acenaphthene $^{*}$ & 3.83 & 3.76 & - & 1.3 \\
Acetone $^{6}$ & -0.24 & -0.24 & 11.2 & 0.064 \\
Anthracene & 4.50 & 4.42 & 0.000001 & 0.0003 \\
Benzene & 2.10 & 2.06 & 0.0455 & 0.052 \\
Benzidine & 1.34 & 1.32 & 0.00386 & 0.008 \\
Benzo(a)anthracene & 5.70 & 5.60 & 0.000027 & 0.108 \\
Benzo(a)pyrene & 6.10 & 6.00 & 0.000014 & 0.14 \\
Bis(2-ethylhexyl)phthalate & 9.60 & 9.44 & 0.0322 & $8.9 \mathrm{E}+05$ \\
Carbon disulfide & 2.20 & 2.16 & 0.0089 & 0.013 \\
Carbon tetrachloride & 2.80 & 2.75 & 0.229 & 1.29 \\
Chlordane & 5.50 & 5.41 & 0.00017 & 0.437 \\
Chlorobenzene & 2.80 & 2.75 & 0.127 & 0.714 \\
Chloroform & 2.00 & 1.97 & 0.188 & 0.175
\end{tabular}


14

Table 4. (continued)

\begin{tabular}{|c|c|c|c|c|}
\hline Contaminant & $\log K_{\text {ow }}$ & $\log \mathrm{K}_{\infty}$ & $\begin{array}{l}\text { WQB } \\
(\mathrm{mg} / \mathrm{L})\end{array}$ & $\begin{array}{c}\text { SQB } \\
(\mathrm{mg} / \mathrm{kg})\end{array}$ \\
\hline 4,4'-DDD & 5.90 & 5.80 & 0.00001 & 0.063 \\
\hline 4,4'-DDT & 6.38 & 6.27 & 0.00004 & 0.745 \\
\hline Di-N-butylphthalate & 4.10 & 4.03 & 0.0327 & 42.1 \\
\hline Di-N-octylphthalate & 9.2 & 9.04 & 0.708 & $7.8 \mathrm{E}+06$ \\
\hline Dibenzofuran & 4.12 & 4.05 & 0.0204 & 2.29 \\
\hline 1,1-Dichloroethane & 1.80 & 1.77 & 0.0466 & 0.027 \\
\hline 1,2-Dichloroethane & 1.50 & 1.47 & 1.10 & 0.325 \\
\hline 1,1-Dichloroethylene & 1.48 & 1.46 & 0.196 & 0.057 \\
\hline 1,2-Dichloroethylene & 1.90 & 1.87 & 0.0312 & 0.023 \\
\hline Dieldrin ${ }^{*}$ & 5.34 & 5.25 & - & 0.11 \\
\hline Diethyl phthalate & 2.50 & 2.46 & 0.220 & 0.634 \\
\hline Endrin* & 4.92 & 4.84 & - & 0.042 \\
\hline Ethylbenzene & 3.10 & 3.05 & 0.389 & 4.36 \\
\hline Fluoranthene ${ }^{*}$ & 5.09 & 5.00 & - & 6.2 \\
\hline Heptachlor & 4.30 & 4.23 & 0.000029 & 0.0049 \\
\hline Hexane & 3.90 & 3.83 & 0.189 & 12.78 \\
\hline Lindane (gamma BHC) & 3.72 & 3.66 & 0.00008 & 0.0037 \\
\hline Methylene chloride & 1.30 & 1.28 & 2.24 & 0.427 \\
\hline Naphthalene & 3.30 & 3.24 & 0.0234 & 0.407 \\
\hline PCB Aroclor-1221 & 7.14 & 7.02 & 0.00027 & 28.27 \\
\hline PCB Aroclor-1232 & 7.14 & 7.02 & 0.00054 & 56.54 \\
\hline PCB Aroclor-1242 & 7.14 & 7.02 & 0.00006 & 6.28 \\
\hline PCB Aroclor-1248 & 7.14 & 7.02 & 0.00001 & 1.05 \\
\hline PCB Aroclor-1254 & 6.03 & 5.93 & 0.00002 & 0.17 \\
\hline PCB Aroclor-1260 & 7.14 & 7.02 & 0.0105 & 1099 \\
\hline PCB (Total) & 7.14 & 7.02 & .000196 & 20.52 \\
\hline Phenanthrene* & 4.54 & 4.46 & - & 1.8 \\
\hline 1,1,2,2-Tetrachloroethane & 2.40 & 2.36 & 0.719 & 1.65 \\
\hline Tetrachloroethylene & 3.4 & 3.34 & 0.125 & 2.73 \\
\hline Toluene & 2.70 & 2.65 & 0.176 & 0.786 \\
\hline 1,1,1-Trichloroethane & 2.50 & 2.46 & 0.0621 & 0.179 \\
\hline 1,1,2-Trichloroethane & 2.00 & 1.97 & 1.4 & 1.31 \\
\hline
\end{tabular}


Table 4. (continued)

\begin{tabular}{lcccc}
\hline \multicolumn{1}{c}{ Contaminant } & $\log \mathrm{K}_{\mathrm{ow}}$ & $\log \mathrm{K}_{\mathrm{\alpha c}}$ & $\begin{array}{c}\mathrm{WQB} \\
(\mathrm{mg} / \mathrm{L})\end{array}$ & $\begin{array}{c}\mathrm{SQB} \\
(\mathrm{mg} / \mathrm{kg})\end{array}$ \\
\hline Trichloroethylene & 2.40 & 2.36 & 0.465 & 1.07 \\
Vinyl chloride & 1.40 & 1.38 & 0.0878 & 0.021 \\
Xylene & 3.20 & 3.15 & 0.086 & 1.21 \\
\hline EPA sediment quality criteria & & & &
\end{tabular}

\subsection{INORGANIC CHEMICALS}

The revised NOAA values for inorganics (Long et al. 1993) will be used as benchmarks at the ORR and the Portsmouth and Paducah Gaseous Diffusion plants.

The data compiled in Long et al. (1993) are from marine and estuarine locations only. The use of the NOAA values for freshwater is appropriate in the absence of reliable freshwater sediment benchmarks. California used both freshwater and saltwater toxicity data in the development of marine water quality standards (Klapow and Lewis 1979). California confronted the question of whether or not it was legitimate to combine freshwater and marine data. A statistical test of medians was applied to freshwater and marine acute toxicity data for As, Cd, $\mathrm{Cr}, \mathrm{Cu}, \mathrm{Pb}, \mathrm{Hg}, \mathrm{Ni}, \mathrm{Ag}$, and $\mathrm{Zn}$, and in only one case (Cd) was there a statistically significant difference in the median response of marine and freshwater organisms. The NOAA values were developed from data from several investigations throughout the United States, and these studies used different approaches to evaluate sediment quality (e.g., toxicity tests, EqP, AET). It is assumed that the use of numerous data and the calculation of percentiles help eliminate the influence of a single (possibly outlier) data point, thereby making the NOAA sediment quality values (ER-L, ER-M) more credible (Long and Morgan 1991).

An effort is under way to produce the same type of data base for freshwater sediments (MacDonald 1993). When that project is complete, the freshwater ER-L and ER-M values should replace the NOAA marine values used in this document.

The ER-L and ER-M values may be used to help identify sites with the potential to cause adverse biological effects. These are not NOAA criteria or standards and are not intended for use in regulatory decisions or any other similar applications (Long and Morgan 1991). However, EPA Region IV has issued a memorandum (Fox 1991) quoting these values as suggested guidance for evaluating sediment contamination data. The memorandum stressed that the purpose of these values was to flag contamination levels of concern and that the contaminated sediments of concern should then undergo biological-effects testing. This also is one purpose of the benchmarks listed in this report.

The reader should note that the NOAA report identifies the chemical concentration above which adverse effects may be first expected and the concentration above which adverse effects are expected in most cases. The intent was not to identify only the lowest concentration of contaminants at which an adverse effect had been observed or predicted for any organism (Long and Morgan 1991). Table 5 lists the NOAA ER-L and ER-M values for selected inorganic chemicals. 
Table 5. Summary of selected available sediment quality benchmarks for inorganic contaminants ( $\mathrm{mg} / \mathrm{kg}$ dry weight) ${ }^{a}$

\begin{tabular}{|c|c|c|c|c|c|c|c|c|}
\hline \multirow[b]{2}{*}{ Metal } & \multirow{2}{*}{$\begin{array}{c}\mathbf{E R}-\mathbf{L}^{b} \\
\mathrm{NOAA}^{b}\end{array}$} & \multirow{2}{*}{$\begin{array}{c}\text { ER-M }{ }^{b} \\
\text { NOAA }^{b}\end{array}$} & \multirow{2}{*}{$\begin{array}{l}\text { Beak } \\
\text { SQG } G^{b, c}\end{array}$} & \multicolumn{2}{|c|}{ Ont. MOE } & \multirow{2}{*}{$\begin{array}{c}\text { Wisconsin } \\
\text { DNR }^{b} \\
\text { SQC }^{b}\end{array}$} & \multicolumn{2}{|c|}{$\begin{array}{l}\text { EPA }^{b} \text { Region V Sediment } \\
\text { Classification }\end{array}$} \\
\hline & & & & Low & Severe & & Nompolluted & Polluted \\
\hline Antimony & 2 & 25 & & & & & & \\
\hline Arsenic & 8.2 & 70 & $17 \ddagger$ & 6 & 33 & 10 & $<3$ & $3-8$ \\
\hline Barium & & & & & & 500 & $<20$ & $20-60$ \\
\hline Cadmium & 1.2 & 9.6 & $2.5 \dagger$ & 0.6 & 10 & 1 & & \\
\hline Chromium & 81 & 370 & $100 \ddagger$ & 26 & 110 & 100 & $<25$ & $25-75$ \\
\hline Copper & 34 & 270 & $85 \ddagger$ & 16 & 110 & 100 & $<25$ & $25-50$ \\
\hline Cyanide & & & & & & & $<0.10$ & $0.1-0.25$ \\
\hline Iron & & & $5.9 \% *$ & $3 \%$ & $4 \%$ & & $<17,000$ & $\begin{array}{l}17,000 \\
25,000\end{array}$ \\
\hline Lead & 46.7 & 218 & $55^{*}$ & 31 & 250 & so & $<40$ & $40-60$ \\
\hline Manganese & & & $1200 *$ & 460 & 1110 & & $<300$ & $300-500$ \\
\hline Mercury & 0.15 & 0.71 & $0.6^{*}$ & 0.2 & 2 & 0.1 & $<1$ & \\
\hline Nickel & 21 & 51.6 & $92 \dagger$ & 16 & 75 & 100 & $<20$ & $20-50$ \\
\hline Silver & 1 & 3.7 & & & & & & \\
\hline Zinc & 150 & 410 & $143^{*}$ & 120 & 820 & 100 & $<90$ & $90-200$ \\
\hline
\end{tabular}

${ }^{a}$ Benchmark values are in $\mathrm{mg} / \mathrm{kg}$ dry weight, "normalized" or expressed on a total organic carbon basis. To normalize to total organic carbon, the dry-weight concentration for each parameter is divided by the fractional mass of the sediment total organic carbon content. ${ }^{b} \mathrm{SQ}=$ sediment quality; ER-L = effects range-low; NOAA = National Oceanic and Atmospheric Administration; ER-M = effects range-median; SQG = sediment quality guideline; DNR = Department of Natural Resources; SQC = sediment quality criterion; EPA $=$ U.S. Environmental Protection Agency.

${ }^{c}$ Beak Consultants (Canada) SOGs, from the SLC method, were derived in $\mathrm{mg} / \mathrm{kg}$ TOC and adjusted to a bulk sediment basis, assuming average 4\% TOC (Hart et al. 1988). Method of derivation: $*=$ background; $\dagger=$ SLC; $\ddagger=$ toxicity test.

${ }^{d}$ Ont. MOE = Ontario Ministry of the Environment; Low (lowest effect level) indicates a level of sediment contamination that can be tolerated by most benthic organisms. It is calculated as the 5th percentile using the SLC method. Severe (severe effect level) indicates the level at which pronounced disturbance of the sediment-dwelling community can be expected. This is the sediment concentration of a compound that would be detrimental to most benthic species. It is calculated as the 95th percentile using the SLC method (Persaud, Jaagumagi, and Hayton 1990). 
the ORR and the Portsmouth and Paducah Gaseous Diffusion plants.

The Ontario Ministry of the Environment (MOE) has prepared provincial sediment quality guidelines (SQGs) using the SLC approach. These values are based on Ontario sediments and benthic species from a wide range of geographical areas within the province (Persaud, Jaagumagi, and Hayton 1990). The lowest effect level (low) is the level at which actual ecotoxic effects become apparent. The severe effect level (severe) represents contaminant levels that could potentially eliminate most of the benthic organisms (Persaud, Jaagumagi, and Hayton 1990). These "low" and "severe" effect values are potential lower and upper benchmarks, respectively.

Beak Consultants in Canada developed potential sediment guidelines for Ontario MOE using a variety of approaches in a tiered system. For the majority of metals, the background value was used as the guideline value. The SLC method was used for As and $\mathrm{Ni}$, and toxicity test methods were used for $\mathrm{Cr}$ and $\mathrm{Cu}$ (Hart et al. 1988).

The Wisconsin Department of Natural Resources (WI DNR) has developed SQC (Geisy and Hoke 1990). These values were derived using the background approach and were based on dredge material suitability for in-water disposal (WADOE 1991).

The EPA Region V Sediment Classification guidelines are for the classification of sediments of Great Lakes Harbors. The "polluted" values listed in Table 5 are qualified as being "moderately polluted" in the guidelines. A third classification, "heavily polluted," is not included herein. Any value greater than the "moderately polluted" value was classified as "heavily polluted." These values were extracted from Geisy and Hoke (1990) as taken from Anon (1977a). The Region V values are considered arbitrary and not well founded scientifically (WADOE 1991). They were considered adequate only for determining the suitability of dredged material for open water disposal. However, the mercury guideline is strictly adhered to, and sediment with concentrations greater than the guideline are considered severely polluted and have to be disposed of by means other than open water disposal (WADOE 1991).

\subsection{POLAR IONIC ORGANIC COMPOUNDS}

Polar organic compounds include methyl and thiocarbamates, triazines, amines and analines, and organic acid pesticides (aliphatic and aromatic acids and esters, phenoxy compounds, and ureas). Unlike nonpolar and nonionic organic contaminants, both polar and ionic organic compounds may adsorb onto sediments by a variety of mechanisms, including hydrophobic interaction, nonspecific ion association, ion exchange, ion-dipole interactions, hydrogen bonding, and complex formation by surface metals (Shea 1988). It is possible that a multiple-term model might account for polar organic partitioning between sediment and aqueous phases, but such a model does not exist (Shea 1988).

The behavior of ionic organic pollutants has not been extensively studied. As with the nonionic organic chemicals, OC appears to be a critical factor in the partitioning behavior in sediments (Jafvert 1990). The critical micelle concentration (Di Toro, Dodge, and Hand 1990) and $\mathrm{pH}$ (Jafvert 1990) also appear to be dominating factors.

The state of Washington has developed sediment quality standards for some ionic organic compounds. These are listed in Table 6. NOAA did not calculate ER-L or ER-M values for polar ionic organic chemicals (Long and Morgan 1991). 
Table 6. Washington State sediment quality standards for ionizable organic compounds (micrograms per kilogram dry weight)

\begin{tabular}{lc}
\hline \multicolumn{1}{c}{ Compound } & $\begin{array}{c}\text { Washington State sediment } \\
\text { quality standard }\end{array}$ \\
\hline Benzoic acid & 650 \\
Benzyl alcohol & 57 \\
Pentachlorophenol & 360 \\
Phenol & 420 \\
2-Methyl phenol & 63 \\
4-Methyl phenol & 670 \\
2,4-Dimethyl phenol & 29 \\
\hline
\end{tabular}

Source: Ginn, T. C., and R. A. Pastorak. 1992. "Assessment and Management of Contaminated Sediments in Puget Sound." pp. 371-401 in Sediment Toxicity Assessment, G. A. Burton, Jr. (eds.). Lewis Publishers, Boca Raton, Fla. 


\section{BENCHMARK USE IN BASELINE ECOLOGICAL RISK ASSESSMENTS}

To evaluate ecological effects of contaminated sediments for a baseline ERA, it is recommended that sediment be collected for toxicity testing, and the benthic macroinvertebrate community be surveyed. This is important because chemical concentrations are not accurate predictors of biological and ecological effects. This is because the percentage of the chemical that is bioavailable may range from 0 to $100 \%$ (Burton and Scott 1992). Benchmarks may be used to determine which chemicals present in the sediment are most likely causing the toxicity. Use of a weight-of-evidence approach enables a more accurate evaluation of adverse ecological impact.

ASTM has approved standard methods for conducting whole-sediment toxicity tests with the freshwater invertebrates Hyalella azteca (an amphipod) and Chironomus tentans and $C$. riparius (both midges) (Ingersoll and Nelson 1990) and with zooplankton Daphnia sp. and Ceriodaphnia sp. (both cladocerans). A draft method exists for the burrowing mayfly Hexagenia limbata (Burton and Scott 1992). Based on a number of sediment contamination studies, the most consistently efficient indicators of acute and short-term chronic toxicity in whole sediments are these aforementioned organisms (Burton and Scott 1992).

A separate technical memorandum will be produced that outlines the toxicity test methods recommended for ERA at the ORR and the Portsmouth and Paducah Gaseous Diffusion plants. 
THIS PAGE INTENTIONALLY LEFT BLANK 


\section{RECOMMENDATIONS}

\subsection{METALS}

In accordance with a memorandum from EPA Region IV (Fox 1991), revised NOAA ER-L values will be used as lower screening benchmarks to flag contaminant levels of concern unless there is evidence that these ER-Ls may be too high. The ER-M is an upper benchmark. Chemical concentrations exceeding the ER-M (median of the effects data) will negatively impact some organisms.

The Ontario MOE "low" values are very low compared with the other benchmarks for As, $\mathrm{Cd}, \mathrm{Cr}$, and $\mathrm{Cu}$; it would be advantageous to compare these values with background concentrations and detection limits. For $\mathrm{Pb}, \mathrm{Hg}, \mathrm{Ni}$, and $\mathrm{Zn}$, the $\mathrm{MOE}$ low values approximate the ER-L. Therefore, these lend support to the use of the NOAA ER-Ls as lower benchmarks. The "low" value for Cd is an important benchmark because freshwater organisms are, in general, more sensitive to Cd than marine organisms (Klapow and Lewis 1979).

Beak guidelines are another set of lower benchmarks. These were developed for use in freshwater systems as broad-based guidelines for Ontario. Because Beak primarily used background concentrations as their guidelines, a comparison with local site-specific background values could provide information regarding the validity of using both the Beak SQG and Ontario MOE values.

Recommended benchmark values for individual metals are discussed in the following text.

Antimony-Data are available from only two geographic regions (Puget Sound/Commencement Bay and San Francisco Bay); therefore, the degree of confidence in the ER-L and ER-M values is moderate (Long and Morgan 1991). However, no criteria are available for comparison from Beak, Ontario MOE, WI DNR, or EPA Region V. Therefore, the ER-L and ER-M will be used as lower and upper benchmarks, respectively.

Arsenic-The ER-L and the Ontario MOE "low" values are approximately equal, lending support to the use of the ER-L as a lower screening benchmark.

Barium-Very little information is available for barium; therefore, the $20-\mathrm{mg} / \mathrm{kg}$ benchmark should be used with caution.

Cadmium-A relatively large amount of data exists for cadmium. The degree of confidence in the ER-L and ER-M values is very high (Long and Morgan 1991). However, Klapow and Lewis (1979) calculated a statistically significant difference in the medians of acute toxicity data from saltwater and freshwater organisms. This supports the findings of Eisler (1985) (Long and Morgan 1991), who found resistance to cadmium higher among marine than freshwater species. Therefore, the freshwater value of Ontario MOE should be used as the lower benchmark.

Chromium-There are some inconsistencies in the Long and Morgan (1991) data available for chromium, possibly due to lack of speciation information. All data were reported as total chromium, whereas the hexavalent form is more toxic than the trivalent form. There also are 
no supporting data from single-chemical spiked-sediment toxicity tests or from the EqP approach (Long and Morgan 1991). The Ontario "low" and Region V "nonpolluted" values are less than the ER-L. The Region V "polluted," WI DNR, Beak, and ER-L values are all approximately equal. Therefore, it is unclear which concentration represents a safe level. The ER-L should be used as the lower benchmark for screening.

Copper-Considerable data exist for copper in sediments. A high degree of confidence exists for the ER-L and ER-M values (Long and Morgan 1991). However, concentrations of about $20 \mathrm{mg} / \mathrm{kg}$ induce sublethal behavioral effects when copper is not tightly chelated or bound to sediments. In one study analyzed by Long and Morgan (1991), the minimum concentration associated with toxic effects was $20 \mathrm{mg} / \mathrm{kg}$. However, EPA classifies copper in sediments below $25 \mathrm{mg} / \mathrm{kg}$ as nonpolluted. Because of these inconsistencies, concentrations exceeding the ER-L would cause copper to be retained as a contaminant of potential concern.

Cyanide-Very little information exists relating sediment concentrations of cyanide to toxic effects. Because WQC and other benchmarks (Suter and Mabrey 1994) are available for cyanide, sediment pore water concentrations should be analyzed and compared to those benchmarks. In the absence of pore water data, the EPA "nonpolluted" value shall be used for screening.

Iron-There is inconsistency between the various benchmarks for iron. Region V lists 1.7 to $2.5 \%$ as being polluted, Ontario MOE lists $3 \%$ as the "low" effect level and $4 \%$ as a "severe" effect level, and Beak lists $5.9 \%$ as background. Because Ontario MOE derived its guidelines for freshwater sediments, the $3 \%$ level will act as the lower benchmark.

Lead-A relatively large amount of data exists for lead. Confidence in the ER-L and ER-M values is moderate and high, respectively. Effects were usually seen at concentrations $>110 \mathrm{mg} / \mathrm{kg}$. This may be because the chemical data were not speciated to indicate the proportion of organic or inorganic lead, and there were no spiked-sediment toxicity test data to confirm the toxic concentrations (Long and Morgan 1991). The Region V "nonpolluted," Ontario "low," Beak, and WI DNR values are similar to the ER-L. This adds confidence to the use of $46.7 \mathrm{mg} / \mathrm{kg}$ as the lower screening benchmark. Concentrations greater than that would result in the need for further investigation.

Manganese-There is no information for manganese in Long and Morgan (1991). The Ontario "low" value shall be used as the lower screening criterion.

Mercury-A moderate amount of data exists for mercury. The confidence in the ER-L and ER-M values should be moderate and high, respectively. Chronic effects are predicted by EqP principles to occur at $0.032 \mathrm{mg} / \mathrm{kg}$, which is considerably lower than the ER-L (Long and Morgan 1991). The WI DNR and Ontario "low" values are similar to the ER-L and add confidence to the use of the ER-L as the lower screening benchmark.

Nickel-Toxicity of nickel is greatly influenced by water hardness and salinity. The degree of confidence in the ER-L and ER-M is moderate. Data were only from field studies; no spiked-sediment toxicity tests or EqP approaches were used (Long and Morgan 1991). No overall effects threshold was apparent in the data compiled by NOAA. Concentrations greater than the ER-L would require further investigation; this value surpasses the Beak, Ontario "low," and Region V "nonpolluted" values. 
Silver-Only a small amount of data is available for silver in sediments. The ER-L and ER-M values hold moderate confidence. There are no data from spiked-sediment toxicity tests or from EqP approaches (Long and Morgan 1991). No criteria are available from Beak, Ontario MOE, WI DNR, or Region V. Use the ER-L as the lower benchmark.

Zinc-Biological effects have not been observed in association with zinc concentrations of $50 \mathrm{mg} / \mathrm{kg}$ or less in sediments (Long and Morgan 1991). The data strongly suggest that sublethal and other sensitive measures of effects may occur at zinc concentrations of between 50 and $125 \mathrm{mg} / \mathrm{kg}$. Confidence in the ER-L and ER-M values is high (Long and Morgan 1991). The ER-L value is consistent with the Ontario "low," WI DNR, and Region $\mathrm{V}$ values; therefore, the ER-L is the lower benchmark.

\subsection{NONIONIC ORGANICS}

The EqP approach will be used to determine benchmarks for nonionic organics and requires the use of WQBs that were developed by Suter and Mabrey (1994). Consult this publication (Suter, Futrell, and Kerchner 1992b), or its most recent update, for a complete discussion of the aquatic benchmarks and their uses.

Sediment benchmarks may be calculated using the EqP approach for every water benchmark available. Each of the benchmarks has a different interpretation (Suter and Mabrey 1994). If concentrations exceed benchmarks that used the National Ambient Water Quality Criteria (NAWQC), the chemicals must be contaminants of concern because the NAWQC are applicable or relevant and appropriate requirements (ARARs). Concentrations that exceed any of the other benchmarks indicate a risk of real effects.

\subsection{IONIC ORGANICS}

Because little information is available for ionic organics, these contaminants should not be eliminated in a screening risk assessment. Preliminary comparisons can be made to the Washington State sediment quality standards (Table 6) to give an indication of the magnitude of the contamination.

WQBs do exist for several of these chemicals (Suter and Mabrey 1994). If pore water concentrations of these chemicals are available, they can be screened against those benchmarks. This was the methodology followed in the Phase I Screening Ecological Risk Assessment for the Clinch River (Cook et al. 1992). 
THIS PAGE INTENTIONALLY LEFT BLANK. 


\section{UNCERTAINTIES/LIMITATIONS}

The EqP methodology has several uncertainties. It relies on an empirical model to compute the pore water concentration from the solid phase measurements. Therefore, there is an uncertainty associated with the use of the model. In addition, uncertainty exists with respect to the $K_{o w}$ associated with the specific chemical because it is an experimentally determined quantity (EPA 1989a). Various types of organic matter present in sediments can have significantly different binding capacities for organic contaminants; the affinity depends in large part on the source and nature of the carbon. For example, organics associated with sediments contaminated with petroleum hydrocarbons would tend to be much less toxic than those associated with sediments whose OC is natural OC (Lee and Jones-Lee 1993).

The assumption that benthic organisms have similar sensitivities to water column species has a level of uncertainty (EPA 1989a). This may be of particular concern for tube-dwelling amphipods. The tubes tend to isolate them from the interstitial water, causing speculation that their exposure is at the sediment/water interface. Additionally, the amphipod tubes are matrices of organics and inorganics; the tube walls could sorb appreciable amounts of organic contaminants, which could alter the availability of sediment-associated contaminants to those organisms (Lee and Jones-Lee 1993).

The EqP approach is known not to work for all nonpolar organics. For example, Nebeker et al. (1989) reported that the organic carbon content of endrin-spiked sediment had little apparent effect on toxicity. It is well known that many pesticides that are sorbed onto soils and sediments are in the form of "bound" pesticide residues that do not participate in equilibrium reactions with water (Lee and Jones-Lee 1993).

The aquatic benchmarks [EPA WQC for the protection of aquatic life and the aquatic benchmarks developed by Suter and Mabrey (1994)] for polychlorinated biphenyls and several polynuclear aromatic hydrocarbons are class criteria based on the cumulative concentration of all

members of the class. In the derivation of sediment benchmarks using the EqP approach and the aquatic benchmarks, it is necessary to apply the class level to each member of the class individually because each has a unique $\mathrm{K}_{\infty}$ (Lake et al. 1990). In environments where one class member comprises the majority of the sediment burden of the class, this approach should be adequate. However, if numerous class constituents are significantly enriched, a safe threshold for the class as a whole may be exceeded even though no individual constituent violates its predicted safe level (based on the aquatic benchmark) (Pavlou 1987).

The Washington State AET and NOAA ER-L and ER-M values have several limitations. Primarily, all or most of the data used in their derivation were based on marine and estuarine systems. These values are being applied to freshwater systems at the ORR and the Portsmouth and Paducah Gaseous Diffusion plants. Differences include physico-chemical characteristics of the system as well as possible differences in sensitivity of biota. Washington State and NOAA values are for single chemicals, although sediments containing chemical mixtures were used for their derivation. The Ontario MOE values were derived to be applicable to sediment types throughout the province of Ontario. The differences between Ontario and east Tennessee, Ohio, and Kentucky sediments and biota introduce a level of uncertainty. 
THIS PAGE INTENTIONALLY LEFT BLANK. 


\section{REFERENCES}

Adams, W. J. 1987. "Bioavailability of Neutral Lipophilic Organic Chemicals Contained on Sediments: A Review." pp. 219-244 in Fate and Effects of Sediment-Bound Chemicals in Aquatic Systems. Proceedings of the Sixth Pellston Workshop, 13-17 August 1984, Florissant, Co. Dickson, K. L., A. W. Maki, and W. A. Brungs (eds.). Pergamon Press. Toronto, Ontario.

Adams, W. J., R. A. Kimerle, and J. W. Barnett, Jr. 1992. "Sediment Quality and Aquatic Life Assessments." Environ. Sci. Technol. 26(10), 1865-1875.

Boese, B. L., H. Lee II, D. T. Specht, R. C. Randall, and M. H. Winsor. 1990. "Comparison of Aqueous and Solid-Phase Uptake for Hexachlorobenzene in the Tellinid Clam Macoma nasuta (Conrad): A Mass Balance Approach." Environ. Toxicol. Chem. 9, 221-231.

Burton, G. A., Jr., and K. J. Scott. 1992. "Sediment Toxicity Evaluations-Their Niche in Ecological Assessments." Environ. Sci. Technol. 26(11), 2068-2075.

Campbell, P.G.C. and A. Tessier. 1991. "Biological Availability of Metals in Sediments: Analytical Approaches." pp. 161-173 in Heavy Metals in the Environment, J.-P. Vernet (ed.), Elsevier Publishing, Amsterdam.

Chapman, P. M. 1989. "Current Approaches to Developing Sediment Quality Criteria." Environ. Toxicol. Chem. 8, 589-599.

Chapman, P. M. 1990. "The Sediment Quality Triad Approach to Determining Pollution-Induced Degradation." Sci. Total Environ. 97/98, 815-825.

Chapman, P. M., E. A. Power, and G. A. Burton, Jr. 1992. "Integrative Assessments in Aquatic Ecosystems." pp. 313-340 in Sediment Toxicity Assessment. G. Allen Burton, Jr. (ed.), Lewis Publishers, Boca Raton, Fla.

Cook, R. B. et al. 1992. Phase 1 Data Summary Report for the Clinch River Remedial Investigations: Health Risk and Ecological Risk Screening Assessment. ORNL/ER-155, Oak Ridge National Laboratory, Oak Ridge, Tenn.

Di Toro, D. M., J. D. Mahony, D. J. Hansen, K. J. Scott, A. R. Carlson, and G. T. Ankley. 1992. "Acid Volatile Sulfide Predicts the Acute Toxicity of Cadmium and Nickel in Sediments." Environ. Sci. Technol. 26, 96-101.

Di Toro, D. M. 1985. "A Particle Interaction Model of Reversible Organic Chemical Sorption." Chemosphere 14(10), 1503-1538.

Di Toro, D. M., L. J. Dodge, and V. C. Hand. 1990. "A Model for Anionic Surfactant Sorption." Environ. Sci. Technol. 24, 1013-1020.

EPA (U.S. Environmental Protection Agency). 1986. Quality Criteria for Water. U.S. Environmental Protection Agency, EPA 440/5-86-001. Washington, D.C. 
EPA (U.S. Environmental Protection Agency). 1989a. Briefing Report to the EPA Science Advisory Board on the Equilibrium Partitioning Approach to Generating Sediment Quality Criteria. EPA 440/5-89-002. Washington D.C.

EPA (U.S. Environmental Protection Agency). 1989b. Evaluation of the Apparent Effects Threshold (AET) Approach for Assessing Sediment Quality. Report of the Sediment Criteria Subcommittee. Science Advisory Board. SAB-EETFC-89-027.

EPA (U.S. Environmental Protection Agency). 1992. Dermal Exposure Assessment: Principles and Applications. EPA/600/8-91/011B. Office of Research and Development. Washington D.C.

EPA (U.S. Environmental Protection Agency). 1993a. Sediment Quality Criteria for the Protection of Benthic Organisms: Acenaphthene. EPA-822-R-93-013. United States Environmental Protection Agency, Washington D.C.

EPA (U.S. Environmental Protection Agency). 1993b. Sediment Quality Criteria for the Protection of Benthic Organisms: Dieldrin. EPA-822-R-93-015. United States Environmental Protection Agency, Washington D.C.

EPA (U.S. Environmental Protection Agency). 1993c. Sediment Quality Criteria for the Protection of Benthic Organisms: Endrin. EPA-822-R-93-016. United States Environmental Protection Agency, Washington D.C.

EPA (U.S. Environmental Protection Agency). 1993d. Sediment Quality Criteria for the Protection of Benthic Organisms: Fluoranthene. EPA-822-R-93-012. United States Environmental Protection Agency, Washington D.C.

EPA (U.S. Environmental Protection Agency). 1993e. Sediment Quality Criteria for the Protection of Benthic Organisms:Phenanthrene. EPA-822-R-93-014. United States Environmental Protection Agency, Washington D.C.

EPA (U.S. Environmental Protection Agency). 1994. Memorandum from Frank Stancil, AERL Athens, GA to Mary Reiley, EPA Office of Water. February 11, 1994. Octanol/Water Partition Coefficients.

Fox, C. 1991. Suggested Guidance for Evaluating Sediment Contamination Data. Memorandum from C. Fox, Sediment Quality Coordinator, to the U.S. EPA Region IV Contaminated Sediments Workgroup. Dec. 20, 1991. Atlanta, Ga.

Geisy, J. P. and R. A. Hoke. 1990. "Freshwater Sediment Quality Criteria: Toxicity Bioassessment." pp. 265-348 in Sediments: Chemistry and Toxicity of In-Place Pollutants. Baudo, R., J. Giesy, and H. Muntau (eds.). Lewis Publishers, Inc. Chelsea, Mich.

Ginn, T. C. and R. A. Pastorak. 1992. "Assessment and Management of Contaminated Sediments in Puget Sound." pp. 371-401 in Sediment Toxicity Assessment, G. A. Burton, Jr. (ed.). Lewis Publishers, Boca Raton, Fla. 
Hart, D.R., J. Fitchko, and P.M. McKee. 1988. Development of Sediment Quality Guidelines Phase II - Guideline Development. Final Report to Ontario Ministry of the Environment, Toronto, Ontario. Beak Consultants Limited, Brampton, Ontario.

Ingersoll, C. G. and M. K. Nelson. 1990. "Testing Sediment Toxicity with Hyalella azteca (Amphipoda) and Chironomus riparius (Diptera)." pp. 93-109 in Aquatic Toxicology and Risk Assessment: Thirteenth Volume, ASTM STP 1096. W. G. Landis and W. H. van der Schalie (eds.). American Society for Testing and Materials, Philadelphia.

Jafvert, C. T. 1990. "Sorption of Organic Acid Compounds to Sediments: Initial Model Development." Environ. Toxicol. Chem. 9, 1259-1268.

Klapow, L. A., and R. H. Lewis. 1979. "Analysis of Toxicity Data for California Marine Water Quality Standards." J. Water Pollut. Control Fed. 51, 2054-2070.

Lake, J. L., N. I. Rubinstein, H. Lee II, C. A. Lake, J. Heltshe, and S. Pavignano. 1990. "Equilibrium Partitioning and Bioaccumulation of Sediment-Associated Contaminants by Infaunal Organisms." Environ. Toxicol. Chem. 9, 1095-1106.

Landrum, P. F. and J. A. Robbins. 1990. "Bioavailability of Sediment-Associated Contaminants to Benthic Invertebrates." pp. 237-263 in Sediments: Chemistry and Toxicity of In-Place Pollutants. Baudo, R., J. Giesy, and H. Muntau (eds.). Lewis Publishers, Inc. Chelsea, Mich.

Lee, G. F. and A. Jones-Lee. 1993. "Problems in Use of Chemical Concentration-Based Sediment Quality Criteria for Regulating Contaminated Sediment." Preprint of Paper Presented at the First International Specialized Conference of Contaminated Aquatic Sediments: Historical Records, Environmental Impact, and Remediation. Milwaukee, Wis., International Association on Water Quality. pp. 439-448.

Long, E. R. and L. G. Morgan. 1991. The Potential for Biological Effects of Sediment-Sorbed Contaminants Tested in the National Status and Trends Program. NOAA Technical Memorandum NOS OMA 52. National Oceanic and Atmospheric Administration.

Long, E.R., D.D. MacDonald, S.L. Smith, and F.D. Calder. 1993. "Incidence of Adverse Biological Effects within Ranges of Chemical Concentrations in Marine and Estuarine Sediments." Submitted to Environmental Management 10/15/93.

MacDonald, D. D. 1993. Memorandum to Clell Ford. Oak Ridge National Laboratory, Environmental Sciences Division, Oak Ridge, Tenn. Jan. 28, 1993.

MacDonald, D. D., S. L. Smith, M. P. Wong, and P. Mudroch. 1992. The Development of Canadian Marine Environmental Quality Guidelines. Environment Canada Ecosystem Sciences and Evaluation Directorate, Ottawa, Ontario.

Maughan, J. T. 1993. "Evaluation of Contaminants in Sediments." pp. 176-205 in Ecological Assessment of Hazardous Waste Sites. J. T. Maughan (ed.). Van Nostrand Reinhold. New York. 
Nebeker, A., G. Schuytema, W. Griffis, J. Barbitta, and J. Carey. 1989. "Effect of Sediment Organic Carbon on Survival of Hyalella Azteca Exposed to DDT and Endrin." Environ. Toxicol. Chem. 8, 705-718.

Neff, J. M., B. W. Cornaby, R. M. Vaga, T. C. Gulbransen, J. A. Scanlon, and D. J. Bean. 1988. "An Evaluation of the Screening Level Concentration Approach for Validation of Sediment Quality Criteria for Freshwater and Saltwater Ecosystems." pp. 115-127 in Aquatic Toxicology and Hazard Assessment: 10th Volume, ASTM STP 971. Adams, W. J., G. A. Chapman, and W. G. Landis (eds.). American Society for Testing and Materials, Philadelphia.

OECD (Organization for Economic Cooperation and Development). 1992. Report of the OECD Workshops on Effects Assessment of Chemicals in Sediment. Organization for Economic Cooperation and Development. OECD Environment Monographs No. 60. Paris.

Pavlou, S. P. 1987. "The Use of the Equilibrium Partitioning Approach in Determining Safe Levels of Contaminants in Marine Sediments." pp. 388-412 in Fate and Effects of SedimentBound Chemicals in Aquatic Systems. Proceedings of the Sixth Pellston Workshop, 13-17 August 1984, Florissant, Co. Dickson, K. L., A. W. Maki, and W. A. Brungs (eds.). Pergamon Press. Toronto, Ontario.

Persaud, D., R. Jaagumagi, and A. Hayton. October 1990. The Provincial Sediment Quality Guidelines. Ontario Ministry of the Environment.

Shea, D. 1988. "Developing National Sediment Quality Criteria." Environ. Sci. Technol. 22(11), 1256-1261.

Southerland, E., M. Kravitz, and T. Wall. 1992. "Management Framework for Contaminated Sediments (The U.S. EPA Sediment Management Strategy)." pp. 341-370 in Sediment Toxicity Assessment, G. A. Burton, Jr. (ed.). Lewis Publishers, Boca Raton, Fla.

Suter, G. W. II, A. Redfearn, R. K. White, and R. A. Shaw. 1992. Approach and Strategy for Performing Ecological Risk Assessments for the Department of Energy Oak Ridge Field Office Environmental Restoration Program. ES/ER/TM-33, Martin Marietta Energy Systems, Inc., Oak Ridge, Tenn.

Suter, G. W. II and J. B. Mabrey. 1994. Toxicological Benchmarks for Screening Potential Contaminants of Concern for Effects on Aquatic Biota: 1994 Revision. ES/ER/TM-96/R1, Oak Ridge National Laboratory, Oak Ridge, Tenn.

WADOE (Washington State Department of Ecology) 1991. Summary of Criteria and Guidelines for Contaminated Freshwater Sediments, Sediment Management Unit. Olympia, Wash. September. 